\title{
TOLERATION, OR CHURCH-STATE RELATIONS? \\ THE DETERMINANT IN NEGOTIATING RELIGIONS \\ IN THE MODERN POLISH-LITHUANIAN \\ COMMONWEALTH
}

The religious, or confessional, history of the modern Europe, split by the Reformation, is, for one thing, a history of religious disputes and the related political conflicts, but it extends in parallel to attempts at regaining the lost unity - and also, to the absorbing history of elaboration of methods of peaceful arrangement of relationships between communities and states that had grown irreversibly diversified in terms of religion.

On the verge of the Reformation process, the secular authorities tried to put an end to it by referring to the time-honoured obligation of their subjects' obedience. However, the Lutheran reformers reminded that "God ought to be obeyed more than men", and regarded the confessional coercion as a tyranny one may, if not ought to, oppose. In face of a threat of religious war, secular authorities attempted therefore to restrict the scope of religious conflicts through top-down issuance of religious peace decrees and, subsequently, tolerance edicts. Polish historians willingly refer to the Confederation of Warsaw, which, however - seen against the period's other instances of religious peace - was distinct not so much in its originality but rather, scope, efficiency, and stability. By the latter half of the sixteenth century, not only the Polish-Lithuanian Commonwealth and the United Provinces of the Northern Netherlands, but also Transylvania, then under the Hungarian rule, attained a high level of religious tolerance, close to equality in rights. ${ }^{1}$ The Polish religious peace ought thus

${ }^{1}$ Ludwig Binder, Grundlagen und Formen der Toleranz in Siebenbürgen bis zur Mitte des 17. Jahrhunderts (Siebenbürgisches Archiv, 3rd Ser., 11, Cologne and 
to be analysed against the background of a whole series of decrees and agreements, which was concluded by the best-known specimen - the Edict of Nantes, $1598 .^{2}$

Discussion was another method that proved popular especially among the humanists and was meant to eliminate the confessional splits; the best known Catholic-Lutheran colloquies took place in Hagenau, Worms, and Regensburg in $1540-1 .^{3}$ A shared characteristics of the numerous meetings of this type was their inefficiency, or perhaps, a peculiar counter-efficiency. Instead of clarifying the disagreements and render the conflicting positions close to one another, the public discussions among theologians turned into a forum of propagating their own views, without paying attention to the interlocutors' arguments. Interestingly enough, no great importance was attached in the sixteenth-century Polish-Lithuanian state to such disputes. It was only in the following century that the organisers of the Colloquium charitativum, held in Torun in 1645 on the wave of irenicism, endeavoured to give the meeting an international dimension.

As the edicts issued by the authorities and scholars' discussions turned out not quite efficient, a forceful solution was subsequently sought for, with miserable political and deplorable social effects. It should suffice to compare William Monter's findings on the number of victims of confessional trials in the sixteenth century, assessed by this author as 5,000 maximum, against the number of victims of religious wars in France, as established by James Wood, with some 270 out of 100,000 inhabitants getting killed each year between

Vienna, 1976); Gábor Barta, 'O problemie tolerancji religijnej w szesnastowiecznym Siedmiogrodzie', in Antoni Cetnarowicz, Csaba G. Kiss, and István Kovács (eds.), Wegry - Polska w Europie Środkowej. Historia - literatura. Księga pamiątkowa ku czci Profesora Wactawa Felczaka (Cracow, 1997), 59-65; Krista Zach, 'Zur Geschichte der Konfessionen in Siebenbürgen im 16. bis 18. Jahrhundert', Süddeutsches Archiv, 24/5 (1981/2), 40-89; Márta Fata, Ungarn, das Reich der Stephanskrone, im Zeitalter der Reformation und Konfessionalisierung. Multiethnizität, Land und Konfession 1500 bis 1700 (Katholisches Leben und Kirchenreform im Zeitalter der Glaubensspaltung, 60, Münster 2000), 97-118.

2 Jörg Haustein, 'Religionsfreiheit im lateinischen Westen. Das Edikt von Nantes und seine Folgen', in Gunter Frank, Jörg Haustein, and Albert de Lange (eds.), Asyl, Toleranz und Religionsfreiheit. Historische Erfahrungen und aktuelle Herausforderungen (Göttingen, 2000), 101-20.

3 Olivier Christin, La paix de religion. L'autonomisation de la raison politique au XVIe siècle (Paris, 1997), 22. 
1560 and $1580 .{ }^{4}$ The intensified religious oppression in the sixteenth century brought about unexpected effects in that political theologians of the Protestant and, thereafter, Catholic camp developed the theory of the right to resist, which later became an important element in the evolution of modern-era communities of subjects into modern societies of citizens.

The idea whereby preservation of peace in the state is valued higher than the striving for the unattainable confessional unity - a concept present since long ago in the Polish political culture - began being accepted with increasing frequency in the Western Europe toward the late sixteenth century. Justus Lipsius, the great authority of the late sixteenth and early seventeenth century, claimed that, given the insurmountable confessional differentiation, the consent for functioning of heterodox communities, if regulated and controlled, is not necessary dangerous for the state. The political interest of a state that had been reinforced resulting from the Reformation transformations began dominating over the religious interest of the Churches, debilitated by the rivalry.

There was a practically functioning broad spectrum of forms of coexistence with the heterodoxies. The worst situation, from today's standpoint, was the case in the extensive peripheral areas where unorthodox views were punished (the Pyrenean and Apennine Peninsulas, Russia). In the conventional 'intolerance scale', next to them are usually placed certain Evangelical territories, e.g. Geneva, which still is considered a theocratic, i.e. clergy-governed, state. ${ }^{5}$ The subsequent

${ }^{4}$ William Monter, 'Heresy Executions in Reformation Europe', in Ole P. Grell and Bob Scribner (eds.), Tolerance and Intolerance in the European Reformation (Cambridge, 1996), 48-65; James B. Wood 'The Impact of the Wars of Religion: A View of France in 1581', The Sixteenth Century Journal, xv, 2 (1984), 131-68.

${ }^{5}$ Leszek Kołakowski ('Krótka rozprawa o teokracji', in idem, Czy Pan Bóg jest szczęśliwy $i$ inne pytania, ed. Zbigniew Mentzel [Cracow, 2009], 248-53) offers three interpretations of the term theocracy; the situation in Geneva in 16th to 17 th c. mostly corresponded with the second option, whereby the Church authorities do not exercise the rule, claiming instead their pretences to control the secular authorities' doings which have a moral significance. See Carl J. Burckhardt, 'Calvin und die theokratische Staatsform', in idem, Vier historische Betrachtungen (Zurich, 1953), 5-13; Alister E. McGrath, A Life of John Calvin: A Study in the Shaping of Western Culture (Oxford, 1990) (I have used the Polish edition of the book, Jan Kalwin. Studium ksztattowania kultury Zachodu, trans. Jerzy Wolak [Warsaw, 2009], 159-89). 
level was characterised by a strict rationing of the dissenters' rights, as was the case with the Lutheran Scandinavia or in the British Isles with regard to the Catholics. At last, the German Reich adopted the rule of territorialisation, which implied the practice of cuius regio eius religio and a whole array of a variety of local solutions. After 1598, France applied a system: combining territorialisation with the statesupervised rationing and regulation. Moreover, the Commonwealth, Transylvania, and Northern Netherlands and, periodically, Bohemia, Moravia and Hungary had internal relationships close to equal rights of the confessions. In practice, the most common standard of the confessional state's attitude towards the dissenters was, however, the ban on public cult as coupled with toleration towards them, or even with ensuring them the right to private cult.

The peaceful relationships occurring in the Polish-Lithuanian state between the various factions of Christianity, tolerance for nonChristians - Jews and Muslims, in the first place - have been of interest not only to historians: it was already in the sixteenth and seventeenth century that they drew attention of the supporters of equal religious rights, which mostly meant theoreticians: thinkers and writers. ${ }^{6}$ This is particularly true for late-Renaissance humanists - those who formulated the postulates for solving the problems of coexistence of the dissidentes in religione in line with the evangelistic love ideals advocated by Erasmus of Rotterdam. After all, the latter once wrote to Archbishop William Warham in as early as 1524, not without rhetorical exaggeration: "Polonia mea est."

The range of humanism's influence in the sixteenth-century Poland can be assessed in different ways. ${ }^{8}$ We often tend to forget, however, that Erasmus's views were opposed by many, at the various sides

${ }^{6}$ Janusz Tazbir, 'Polskie i obce opinie o konfederacji warszawskiej', Odrodzenie $i$ Reformacja w Polsce, xix (1974), 151-60.

${ }^{7}$ Korespondencja Erazma $z$ Rotterdamu z Polakami, trans. and ed. Maria Cytowska (Warsaw, 1965), 5; see Henryk D. Wojtyska, 'Polonia "il Regno di Erasmo" nella prima metà del XVI secolo', in The Common Christian Roots of the European Nations: An International Colloquium in the Vatican, ii (Florence, 1982), 88-93.

${ }^{8}$ George H. Williams, 'Erasmianism in Poland: An Account of a Major, though Ever Diminishing, Current in Sixteenth-Century Polish Humanism and Religion, 1518-1605', The Polish Review, xxii, 3 (1977), 3-50; Juliusz Domański, 'Der Einfluß des Erasmianismus und die Reformation in Polen', Acta Poloniae Historica, 55 (1987), 41-56. 
of confessional barricades which were fervently erected by the followers of Rome and Wittenberg, later also of Geneva. Thus, the religious relations in Poland in the sixteenth century were perceived negatively by some political theorists who adopted the apparently obvious assumption that a state must be confessional; no other model was conceivable to them, as Antoni Mączak points out. ${ }^{9}$ There was a commonplace conviction that wherever the authorities, along with those professing the ruling religions (which usually meant the ruler's religion), are tolerant toward the adherents of other confessions, there is an incessant jeopardy of conflict and, therefore, a constant threat to the state owing to disloyalty of the dissenter subjects. ${ }^{10}$

It is worth noting, by the way, that the doctrine rendering the state's strength dependent on the level of confessional homogenisation of its population is reminiscent of the views of our contemporary theoreticians who associate the safety of a state with its ethnic homogeneity with the national awareness of its inhabitants. ${ }^{11}$ In the sixteenth and seventeenth century, however, it was the ethnic mosaic of the Polish-Lithuanian state that made some political authors disturbed. Of an issue to them was, instead, the religious and confessional multifariousness and, in the first place, the impotence of the Commonwealth authorities, incomprehensible for many, in that they were long refraining from imposition of the confessional coercion - the option seemingly so beneficial to the state - even where the legal and political realities so allowed. According to this theory, the Kingdom of Poland and the Grand Duchy of Lithuania, which from 1569 onwards made up the Commonwealth of the Two Nations - a multi-denominational state, without a strong executive power or efficient administration - must have been politically weak, doomed to internal conflicts, external interventions, and,

${ }^{9}$ Antoni Mączak, Rządzacy i rzadzeni. Wtadza $i$ społeczeństwo w Europie wczesnonowożytnej (2nd edn, Warsaw, 2002), 80.

${ }_{10}$ Zbigniew Ogonowski, Filozofia polityczna w Polsce XVII w. i tradycje demokracji europejskiej (Renesans i reformacja, studia z historii filozofii i idei, 9, Warsaw, 1992), 105. The conviction that dissenters are potentially disloyal people continued for a long time. See John H. Newman, A Letter Addressed to His Grace the Duke of Norfolk on Occasion of Mr. Gladstone's Recent Expostulation, <http://www.newmanreader. org/works/anglicans/volume2/gladstone/index.html> [Accessed 30 April 2013].

${ }^{11}$ Tomasz Kizwalter, O nowoczesności narodu. Przypadek polski (Warsaw, 1999), 288-321. 
finally, roll down into the abyss of religious wars, and eventually collapse. But was it the faith-related freedoms as reinforced in 1573 by the Warsaw Confederation that formed the background of the Polish-Lithuanian state's crisis occurring since the middle of the seventeenth century?

At the end of the sixteenth century, the belief that a fall of the Commonwealth was forthcoming was advocated, among others, by an author using the penname of Gulielmus Rossæus, who was associated with the French Catholic League. ${ }^{12}$ On the margin of one of his works whose main argument was Henry of Navarre's illegitimate claims to the throne of France, he dealt with the confessional relations in the Commonwealth. The fact that the tradition of denominational and religious diversity had been older in Poland than the Reformation was unknown to Rossæus, and he focused on discussing the effects of the actions of Evangelicals, particularly Calvinists - the central target of his attacks - which apparently were menacing to the state. ${ }^{13}$ In Rossæus's view, it was them to have brought about the equal rights for non-Catholics in the Commonwealth; he was particularly resentful of the toleration for the Anti-Trinitarians, whom he considered, along with Calvinists, to be willing to cooperate with Islam. ${ }^{14}$

12 The pseudonym Rossæus, popular since Thomas More's time, was used by English Catholic clergyman William Rainolds (Reynolds), active in France and the Netherlands; the other possible authors using this penname being bishop Gillaume Rose, or even Jean Boucher. See John W. Allen, A History of Political Thought in the Sixteenth Century (London, 1941), 351; Władysław J. Stankiewicz, Politics and Religion in Seventeenth-Century France: A Study of Political Ideas from Monarchomachs to Bayle, as Reflected in the Toleration Controversy (Berkeley and Los Angeles, 1960), 39.

${ }^{13}$ Guilelmus Rossæus, De iusta reipub. [licae] christianae in reges impios et haereticos authoritate. Iustissimaque Catholicorum ad Henricum Navarraeum et quemcunque haereticum a regno Galliae repellendum confederatione (Antverpiae: Keerbergius, 1592), 268-72; cf. John H. M. Salmon, 'Catholic Resistance Theory, Ultramontanism, and the Royalist Response, 1580-1620', in J. H. Burns and Mark Goldie (eds.), The Cambridge History of Political Thought, 1450-1700 (Cambridge, 1991), 219-53.

14 This accusation was a standard in the anti-Protestant polemics of the 16 th century. It became apparently meaningful in the following century, owing to Hungarian and Bohemian Evangelicals who, of two evils, preferred to have 'a Turk than the Pope', and even made the Dutch Calvinists interested in Islam. See Marianne E.H.N. Mout, 'Calvinoturcisme in de zeventiende eeuw. Comenius, Leidse oriëntalisten en de Turkse bijbel', Tijdschrift voor Geschiedenis, xci, 4 (1978), 576-607. 
Not only did the Polish and Lithuanian Evangelicals, "Ariani, tot Tritheitae, tot Trinitarij, plurimi Samosateniani" disturb the internal peace; they were also responsible for the neighbouring countries' hostile policy:

Ergo Calvinistae tantulo tempore ita infirmarant et corruperant potentissimum antea regnum Poloniae, ut quoad civilia, omnes vicini principes et imminerent, illudque divisuros inter se brevi ominarentur. Moscovita quidem manifeste ei inhiabat, et de Prussia adimenda magnam spem conceperat, Suecus lacessabat, civitates maritimae ab eius se imperio subtrahebant, Turca certo confidebat ... ${ }^{15}$

To Rossæus's mind, Poland and Lithuania were saved from annihilation by the Counter-Reformation, as coupled with

excellentissimi regis Stephani diligentia, iustitia, et fortitudo, eandem erexit et instauravit, qui prophanas illas haereticorum sectas quam poterat studiosissime recidens, et unam Catholicam religionem restaurans atque amplificans, simul regni sui fines, et una Catholicae religionis pomeriae faeliciter et gloriose dilatavit ... et in ijs locis extirpata partim Lutheranorum, partim Calvinistarum, partim Arianorum, partim Graecorum impietate, Catholicam religionem restituit ... ${ }^{16}$

This interesting interpretation of the Commonwealth's history, albeit not having much in common with the reality, reminds one also of how the confessional situation of the appraiser determined his view and opinions - a dependence so characteristic to the tolerance discourse. Suffice it to compare the argument of the above-quoted Catholic author against the views of Andrzej Lubieniecki (d. 1623), to clearly see that both made use of a similar, though completely reversed, perspective. For Rossæus, as a member of the Catholic Church, considering itself to be the reigning entity - similarly as to Piotr Skarga, somewhat later - equality of rights for the heterodoxies led to

${ }^{15}$ Rossæus refers to the opinions of Stanisław Warszewicki and Stanisław Orzechowski; Rossæus, De iusta, 270.

${ }^{16}$ Ibidem, 272. Interestingly enough, Philipp von Zesen (1619-89), German irenicist and adherent of liberty of conscience, regarded Bathory as the model of tolerant ruler, stating, i.a.: "Eben derselbe hat oftmals gesagt. Ich bin ein König über Völker und nicht über Gewissen", see idem, Wider den Gewissenzwang, ed. Ferdinand van Ingen, in Philipp von Zesen, Sämtliche Werke, xiii (Berlin and New York, 1984), 255-7. 
a collapse of the state; for Lubieniecki, member of the Polish Brethren, it was the source of the state's strength. Rossæus's stance was that it was only the influence of the Counter-Reformation that could save the Commonwealth from a decline, whereas Lubieniecki saw it as the greatest threat to the Polish-Lithuanian state. ${ }^{17}$ This contradiction is striking but comprehensible, as both authors rendered their historiosophical evaluations subject to their denominational perspective.

As we know today, the Polish-Lithuanian state never became plunged in religious conflicts, contrary to what the author of De iusta Reipublicae christianae ... (1592) forecast (and unlike France in sixteenth century, or Germany in sixteenth and seventeenth centuries). On the contrary: during the reign of King Sigismund II Augustus, Stephen Bathory, and then on, Sigismund III Vasa, the multi-denominational Commonwealth confirmed its position as a regional power in the Eastern Europe, which undermined the relevance of the theory that defined a state's strength in inverse proportion to the level of its denominational diversity, and was reflected in Polish utterances on this subject-matter.

In the late sixteenth and early seventeenth century, the gravity centre in the argumentation employed in the discussions on confessional policies began moving from the theological into political sphere. ${ }^{18}$ The doctrine of confessional state, in association with the idea of raison d'état, finally brought about a positive outcome to the State-Church relationships and to the situation of the dissenters in the seventeenth century. In the states which entered at that time the path of absolutistic modernisation, this approach stabilised their situation - true, often at a low level of powers granted, but this still marked a clear progress, compared to the religious wars period. Regardless of the differences in the views of confessionalisation and its relations with modernisation, it may be accepted that the standardisation of confessional relations in the spirit of a political neo-stoicism generally led to their stabilisation in the Western Europe. In Northern Netherlands and in England, the areas where the

17 Janusz Tazbir, 'Wstęp', in Andrzej Lubieniecki, Poloneutychia, ed. Alina Linda et al. (Warsaw and Lodz, 1982), VI-VII.

${ }^{18}$ Hans R. Guggisberg, 'Wandel der Argumente für religiöse Toleranz und Glaubensfreiheit im 16. und 17. Jahrhundert', in H. Lutz (ed.), Zur Geschichte der Toleranz und Religionsfreiheit (Wege der Forschung, 246, Darmstadt, 1977), 458. 
Calvinist political doctrines exerted their strongest impact, concepts even occurred whereby the state's control over the Church would turn into a separation of the two institutions.

As for the Commonwealth, where the raison-d'état ideas as defined by Catholic neo-stoics arrived at an early stage, an attempt at their practical application by reinstating a confessional (i.e. Catholic) character to the state, in the early years of the seventeenth century, proved abortive. Relying on the account of Thomas Roe, English diplomat and keen observer of the Eastern-European developments, what Sigismund III was after was, at the utmost, a soft religious unification of the society (let us highlight the soft aspect) and, in the longer run, probably its Catholic confessionalisation. ${ }^{19}$ Before then, in the sixteenth century, the Polish and Lithuanian political elites abode by the raison-d'état rules avant la lettre, in the Commonwealth's multidenominational and multi-religious society, whereas the European coercion-based pattern of confessional policy seemed deterring to them. When the country's Catholic-dominated elites made an attempt, in the following century, to resume the confessional state model, as prevalent in Europe at the time, it proved to be a difficult exercise, and resulting from the efforts benefitting the Catholic confessionalisation, the position of the Catholic Church, rather than Commonwealth, grew reinforced. It fell to the Commonwealth's lot, however, to pay at a later date for the conflict with the dissenters, which - taken advantage of by the country's expansive neighbours - occurred in the following century to be an instrument of its dismantling.

The seventeenth century was a period of wars the Commonwealth waged against its non-Catholic neighbours: the Orthodox Russia, Lutheran Sweden, and Evangelical Brandenburg/Prussia. Then, a war against the Muslim Ottoman Empire began, and would not end till the late seventeenth century; these conflicts clearly reinforced the Catholic influences. The Catholic Church successfully referred not only to political reasons, to the 'bulwark of Christianity' idea, but also, or perhaps primarily, to the social emotions and strengthening xenophobia. ${ }^{20}$ Insofar as the early-seventeenth-century Commonwealth still

${ }^{19}$ Jan Seredyka, 'Sir Tomasz Roe o polityce wyznaniowej Zygmunta III', Sprawozdania Opolskiego Towarzystwa Przyjaciót Nauk, Ser. A, 18 (1981), 43-4.

${ }^{20}$ Janusz Tazbir, 'Ksenofobia w Polsce XVI i XVII w.', in idem, Arianie i katolicy (Warsaw, 1971), 238-78; idem, 'Stosunek do obcych w dobie baroku', in Zofia 
ranked amongst the most tolerant European countries, it lost this position in the century's second half. ${ }^{21}$ It probably was then that the syndrome described as 'a Pole equals a Catholic' was begotten, with the result that dissenters were excluded from the community of the Commonwealth's citizens.

The apt opinion has solidified whereby the Catholic Church in the Commonwealth, in its rivalry for the rule of people's hearts and minds, made use, primarily, of the Society of Jesus' educational system. It is worth bearing in mind, though, how important was the role the judicature - especially, the tribunals - played in this matter. It was already by means of the regulations of the Crown Tribunal, issued under the reign of Stephen Bathory (1578), that the Catholic clergy gained a strong position in this body, and consequently, in the later years, they strove for the tribunals to consider not only ecclesial income cases and to extend their competencies to trials for heresy, apostasy, blasphemy (as a broad concept), ${ }^{22}$ and the cases tried after 1658 ex regestro arianismi. ${ }^{23}$ Having at its disposal the school system and the influences in the judiciary, and subsequently making use of the advantageous political conditions, the Catholic Church aimed at breaking the equal denominational rights determined in 1573, and afterwards, at restricting the scope of tolerance for the dissenters. Attempts were also made at confessionalising the Commonwealth's society, an increasingly clearly belated project. King John II Casimir's Lvov Oath of 1656 and the expulsion of the Polish Brethren, adopted by the diet in 1658, signified the final breakage of the bonds with those political thought currents that soon after bore fruit in the works of Baruch Spinoza and John Locke. ${ }^{24}$

Stefanowska (ed.), Swojskość $i$ cudzoziemszczyzna $w$ dziejach kultury polskiej (Warsaw, 1973), 80-112.

${ }^{21}$ John Marshall, John Locke, Toleration and Early Enlightenment Culture (Cambridge Studies in Early Modern British History, Cambridge, 2006), 138.

${ }^{22}$ Oswald Balzer, Geneza Trybunału Koronnego. Studyum z dziejów sądownictwa polskiego XVI w. (Warsaw, 1886), 319-20, 327, 329-30.

${ }^{23}$ Marek Wajsblum, 'Juxta jus scriptum judicabo...', in idem, Ex regestro arianismi. Szkice z dziejów upadku protestantyzmu w Małopolsce (Cracow, 1937-48), 65-95.

${ }^{24}$ Janusz Tazbir, 'Reformacja jako ruch umysłowy', in idem, Szlachta i teologowie. Studia $z$ dziejów polskiej kontrreformacji (Warsaw, 1987), 52; Jonathan I. Israel, 'Spinoza, Locke and the Enlightenment Battle for Toleration', in Ole P. Grell and Roy Porter (eds.), Toleration in Enlightenment Europe (Cambridge, 2000), 102-13. 
At the same time, the conviction was getting shape in the Western Europe whereby it was the rationing of religious life and limitation of the dissenters' rights that was the embers of conflicts weakening the state. The complex determinants of the State-Church(es) relations and their political consequences were only apparent, in the seventeenth century, to the most eminent theoreticians - particularly those who combined such afterthought with the experience of living in a society deeply diversified confession-wise; in Western Europe, primarily the English and the Dutch formed such societies. It was in England that the political writers of the Revolution and Restoration period strenuously worked on a theory of the state's sovereign power and the issue of stable relations between the state and Churches of different denominations. ${ }^{25}$ By way of example, let us just recall the two thinkers who assumed differing positions and therefore formulating dissimilar conclusions: Thomas Hobbes, advocate of state's control over the religious life, ${ }^{26}$ and Roger Williams, protagonist of faith freedoms. ${ }^{27}$

Characteristically enough, the projects of a radical solution of quitting the traditional association of secular power and sacred authority - thus, inclining towards a separation of the Church and the State, with a resultant secularisation of the latter - were formulated by adherents of so-called civic religion, whose milieus were permeated with the republican ideas of opposition against a strong central authority. ${ }^{28}$ Enough to remind that it was in the Northern Netherlands of the 'genuine freedom' period, under the rule of Johan de Witt, an opponent of the 'Orange dynasty', that republican government concepts were developed by the De la Court brothers who, among other things, demanded that the Reformed clergy, quite 'Orange

${ }^{25}$ Arihiro Fukuda, Sovereignty and the Sword: Harrington, Hobbes, and Mixed Government in the English Civil Wars (Oxford, 1997), 141-53.

${ }^{26}$ Michael Oakeshott, Hobbes on Civil Association (Oxford, 1975), 69-72.

${ }^{27}$ Roger Williams, The bloudy tenent of persecution, for Cause of Conscience: Discussed in a Conference between Truth and Peace, ed. Samuel L. Caldwell, in The Complete Writings of Roger Williams, iii (New York, 1963); Perry Miller, Roger Williams: His Contribution to the American Tradition (Indianapolis, 1953), 439-40; Tadeusz J. Zieliński, Roger Williams. Twórca nowoczesnych stosunków państwo-kościót (Warsaw, 1997), 210-47.

${ }^{28}$ Simone Zurbuchen, 'Republicanism and Toleration', in Martin van Gelderen and Quentin Skinner (eds.), Republicanism: A Shared European Heritage, ii: The Values of Republicanism in Early Modern Europe (Cambridge, 2002), 47. 
house-inclined' as they were, be removed from political affairs, so that full religious and intellectual freedom could be preserved. ${ }^{29}$ Similar, unambiguously anticlerical, views are found in the ideology of the English republicanism, which is not to say that those ideas were antireligious. The continuers of James Harrington's concepts in the late seventeenth and early eighteenth century not so much fought Anglicanism as strove for transforming it into a kind of civic cult. ${ }^{30}$

Somewhat earlier on, in Holland, Baruch Spinoza worked on his Tractatus Theologico-Politicus which demanded a libertas philosophandi - a broad concept including freedom of thought and utterance. ${ }^{31}$ As Leszek Kołakowski reminds, the treatise also postulated

the rule of enlightened elite proving able to preserve the climate of political freedom in the interest of permanence of authority and exercising their rule in line with the interest of the people, rather than according to the people's momentary opinion ... acting in a way so as to arouse among the masses the conviction that it is them who make the decisions of relevance to the state ... ${ }^{32}$

Yet, it is clear that the said elites are the secular authorities of Holland in the de Witt period, whilst the Tractatus was correctly interpreted as a design to neutralise the Reformed clergy's influence on the public affairs. ${ }^{33}$ Spinoza rejected even the views of those advocating the equivalence of secular and clerical authorities (in Chapter XIX):

${ }^{29}$ Ernst H. Kossmann, Political Thought in the Dutch Republic: Three Studies (Amsterdam, 2000), 60-74.

${ }^{30}$ J. A. Champion, The Pillars of Priestcraft Shaken: The Church of England and its Enemies, 1660-1730 (Cambridge Studies in Early Modern British History, Cambridge, 1992), 179.

${ }^{31}$ Spinoza, Opera. Werke, i: Tractatus theologico-politicus. Theologisch-politischer Traktat (hereafter: Spinoza, Tractatus), ed. Günter Gawlick and Friedrich Niewohner (Darmstadt, 1989), chap. XX: 'Ostenditur in libera republica unicuique et sentire, quae velit, et quae sentiat, dicere licere', pp. 600-20; Steven Nadler, Spinoza: A Life (Cambridge, 1999) (I have used the Polish edition of the book, Spinoza, trans. Władysław Jeżewski [Warszawa, 2002], 270 ff.); Jonathan I. Israel, Radical Enlightenment: Philosophy and the Making of Modernity 1650-1750 (Oxford, 2001), 265-70.

${ }^{32}$ Leszek Kołakowski, Jednostka i nieskończoność. Wolność $i$ antynomie wolności w filozofii Spinozy (Warsaw, 1958), 531.

${ }^{33}$ Ernestine van der Wall, 'The Tractatus Theologico-Politicus and Dutch Calvinism, 1670-1700', Studia Spinozana, 11 (1995), 201-26, here: 206 f. 
Sed eos hac ratione imperium dividere, imo viam ad imperium affectare, infra in hoc ipso capite videbimus; nam prius ostendere volo religionem vim juris accipere ex solo eorum decreto, qui jus imperandi habent; et Deum nullum singulare regnum in homines habere nisi per eos, qui imperium tenent, et praeterea quod religionis cultus et pietatis exercitium reipublicae paci et utilitati accommodari, et consequenter a solis summis potestatibus determinari debet, quaeque adeo ejus etiam interpretes debent esse. ${ }^{34}$

There is no coincidence, then, that it was on his emigration to Holland that John Locke, the other pillar of the early Enlightenment era, who soon before then had joined the Whigs' conspiracies against the Catholic ruler James II, laid, in his Epistola de tolerantia (1689), the foundations for the doctrine of separation of the Church and the State - possibly influenced by the Socinian concepts, ${ }^{35}$ but certainly making use of the ideas of the Dutch Staatsgezinden, i.e. adherents of supremacy of secular over sacred authority. Locke's concept deemed the Church of England to be a voluntary association independent upon the state authorities, this being the grounds for the guarantees of tolerance. ${ }^{36}$ Regardless of certain differences between Spinoza and Locke in the depiction of the issue, and of the political limitations of the latter's concept - as remarked by Jan de Tex and more recently reminded by Jonathan I. Israel ${ }^{37}$ - the aforementioned two memorable treatises, claiming the freedom of thought and utterance and postulating separation of Church and State, laid the foundations for development of the Protestant Enlightenment. ${ }^{38}$

34 Spinoza, Tractatus, 572.

35 Zbigniew Ogonowski, 'Słowo wstępne do wydania polskiego', in John Locke, List o tolerancji. Tekst łaciński i przekład polski, trans. Leon Joachimowicz (Warsaw, 1963), viii-ix; Zbigniew Ogonowski, Socynianizm a oświecenie. Studia nad myśla filozoficzno-polityczna arian w Polsce XVII wieku (Warsaw, 1966), 560-4.

${ }^{36}$ Richard Ashcraft, Revolutionary politics and Locke's Two Treatises of Government (Princeton, 1986), 313-59; cf. John Marshall, John Locke: Resistance, Religion, Responsibility (Cambridge Studies in Early Modern British History, Cambridge, 1994), 329-83.

${ }^{37}$ Jan de Tex, Locke en Spinoza over de tolerantie (Amsterdam, 1926), 123-30; Israel, Radical Enlightenment, 265; idem, 'Locke, Spinoza and the Philosophical Debate Concerning Toleration in the Early Enlightenment (c. 1650-1750)', Mededelingen van de Afdeling Letterkunde Royal Netherlands Academy of Sciences, N.S., 62 (1999), 5-19.

${ }^{38}$ J.G.A. Pocock, Barbarism and religion, i: The Enlightenment of Edward Gibbon, 1737-1764 (Cambridge, 1999), 56-7. 
In the late seventeenth and early eighteenth century, the Whig-ruled England saw deliberations on the State-Church relations conducted in the republican and deist milieus, but even there Locke's views were initially not accepted. ${ }^{39}$ John Toland was of opinion that existence of a State religion was a natural thing, and the cult ought to be controlled by the authorities, albeit he hoped that establishing Anglicanism as the ruling denomination should warrant tolerance to the other confessions, deemed private - tolerance being "a truly Protestant principle". ${ }^{40}$ Toland referred to the views of James Harrington who also maintained that the State ought to have its official cult. ${ }^{41}$ Almost in parallel, however, Matthew Tindal demanded freedom of the press and respect for freedom of thought, in reference to Locke's views, ${ }^{42}$ whilst Toland reported to his compatriots on Spinoza's ideas. ${ }^{43}$

The origins and the emergence of the main currents of the early Enlightenment are not completely clear yet; in the specific sphere of religious relations, Spinoza's and Locke's concepts need being approached separately, with the third great 'tolerantionist' (which he certainly was), Pierre Bayle, being borne in mind. ${ }^{44}$ This applies also to the political views of the first generations of enlightened republicans, where the earlier version of classical republicanism, referring to the Roman tradition, needs being meticulously discerned from democratic republicanism which was then in its statu nascendi..$^{45}$ Regardless of the doubts and differences appearing between the enlightened 'founding fathers', there was no discord among them (as confirmed by Immanuel Kant, who wrote his works in the late-Enlightenment period ${ }^{46}$ ) about

${ }^{39}$ Ole P. Grell and Roy Porter, 'Toleration in Enlightenment Europe', in iidem (eds.), Toleration in Enlightenment Europe, 1-22.

${ }^{40}$ John Toland, Anglia libera: Or the Limitation and Succession of the Crown of England explain'd and Asserted (London, 1701, rep. New York, 1979), 4; idem, The State-anatomy of Great Britain ... (London, 1717), 21, 95-6.

${ }^{41}$ The Oceana and Other Works of James Harrington ... with an Exact Account of his Life, ed. John Toland (London, 1771, rep., Aalen, 1980), 474-6.

${ }^{42}$ Matthew Tindal, 'Of the Liberty of the Press', in idem, Four Discourses on the Following Subjects ... (London, 1709), 329.

${ }^{43}$ Zurbuchen, 'Republicanism', 60-4.

${ }^{44}$ Jonathan I. Israel, Enlightenment Contested: Philosophy, Modernity, and the Emancipation of Man 1670-1752 (Oxford and New York, 2008), 135-63.

45 Ibidem, 240-63.

${ }^{46}$ Immanuel Kant, Die Metaphysik der Sitten (I have used the Polish edition: Metafizyka moralności, trans. Ewa Nowak, [Biblioteka Klasyków Filozofii, Warsaw, 2007], 224-5). 
the postulated supremacy of politics (the State) over religion (the Church), no confessional coercion being acceptable. In France, it was even considered, in the 1770s, whether to remove from the royal oath the obligation to fight 'the heretics', but the phrase was eventually retained out of respect for the tradition. ${ }^{47}$

Regardless of the doubts about the genetic relations between the Reformation in general and Calvinism in particular, on the one hand, and the Enlightenment-era modernisation of the European societies, ${ }^{48}$ on the other, there is no doubt that the idea of cutting the Gordian knot by secularising the confessional state bearing the dilemma of parallel existence of multiple religions within it was conceived in the latter half of the seventeenth century in Holland and England, the 'free' - which meant, distant from absolutism - Protestant countries. In that very time, however, as the West of Europe witnessed the emergence of the concepts - so dear to Polish elites of the 'nobility's democracy' period - combining reluctance toward a strong executive monarchal authority with postulates of religious freedom as well as liberty of thought and utterance, the religious and State-Church relations in the Commonwealth proved already much different from the equality of denominations which a hundred years earlier aroused admiration among some and condemnation among the others.

The Catholic confessionalisation policy applied to the Polish-Lithuanian state in the late sixteenth century, intensified in second half of seventeenth century - and very belated, be it in relation to the Habsburg domains bordering on Poland, ${ }^{49}$ plus relatively not-quite-efficient, for

${ }^{47}$ Chantal Grell, 'The sacre of Louis XVI: The End of a Myth', in Michael Schaich (ed.), Monarchy and Religion: The Transformation of Royal Culture in Eighteenth-Century Europe (Studies of the German Historical Institute London, Oxford et al., 2007), 345-6.

${ }^{48}$ Hugh R. Trevor-Roper, 'The Religious Origins of the Enlightenment', in idem, Religion, the Reformation and Social Change, and Other Essays (London, 1967), 193-236.

${ }^{49}$ The literature dealing with re-Catholicisation of the Bohemian lands in the former half of the 17th century is extensive; see, e.g., Jindřich Francek (ed.), Rekatolizace v Českých zemích. Sborník př́spěvkủ z konference v Jičínĕ, konané 10. zár̆í 1993 (Pardubice, 1995); Tomáš Knoz (ed.), Morava $v$ době renesance a reformace. (Sborník príspevku proslovených ve dnech 6. ledna az 24. února 1999 v rámci prednáskového cyklu Moravského zemského muzea v Brne) (Brno, 2001); Jörg Deventer, Gegenreformation in Schlesien. Die habsburgische Rekatholisierungspolitik in Glogau und Schweidnitz 1526-1707 (Cologne et al., 2003). 
political-systemic reasons - had its far-reaching consequences. The confessionalisation action reached its climax in the former half of the eighteenth century - the time the non-Catholic nobility had their political rights initially limited and subsequently abolished, at the diets held in 1717 and $1733-5,{ }^{50}$ whereas the Lutheran authorities of Gdańsk (Danzig), Elbląg (Elbing) and Torun (Thorn) were intimidated and humiliated on the occasion of the so-called Torun affair of $1724 . .^{51}$ However, one of the major consequences of the strivings for reconstruction of the early-modern confessional state model, which was becoming history in the west of Europe, turned out to be the facilitation in the eighteenth century of a political, initially mostly propagandist, use of the religious conflict by the expansionist neighbour states. ${ }^{52}$ When in the early 1770s the Orthodox Russia and Evangelical Prussia embarked on the first partition of the Commonwealth under the pretext of acting in defence of the rights of non-Catholic religious communities, ${ }^{53}$ the enlightened European elites voiced no significant protest: ${ }^{54}$ their care about the Protestants oppressed in Catholic countries was tactical, and, with only sparse exceptions, they did not understand the specific Polish problems, nor were even willing to. ${ }^{55}$

${ }^{50}$ Wojciech Kriegseisen, 'Between Intolerance and Persecution: Polish and Lithuanian Protestants in the 18th Century', Acta Poloniae Historica, 73 (1996), 13-27.

${ }^{51}$ Stanisław Salmonowicz, 'O toruńskim tumulcie z roku 1724', Odrodzenie $i$ Reformacja $w$ Polsce, 28 (1983), 161-84; Marian Biskup (ed.), Historia Torunia, ii, 3: Między barokiem a oświeceniem (1660-1793) (Toruń, 1996), 182-205.

52 Józef Feldman, 'Sprawa dysydencka za Augusta II', Reformacja w Polsce, iii, 9-10 (1924), 89-116; Gotthold Rhode, Brandenburg-Preußen und die Protestanten in Polen 1640-1740. Ein Jahrhundert preußischer Schutzpolitik für eine unterdrückte Minderheit (Leipzig, 1941); L. R. Lewitter, 'Peter the Great and Polish Dissenters', Slavonic and East European Review, xxxiii (80) (1954/5), 75-101.

${ }^{53}$ Bernhard Stasiewski, 'Zur Kirchenpolitik der Nachbarstaaten Polen-Litauens in der zweiten Hälfte des 18. Jahrhunderts', in Friedhelm B. Kaiser and Bernhard Stasiewski (eds.), Die erste polnische Teilung 1772 (Cologne and Vienna, 1974), 96-115; Boris V. Nosov, Ustanovlenie rossiǔskogo gospodstva v Rechi Pospolitoı 1756-1768 gg. (Moscow, 2004), 321-56.

${ }^{54}$ Ryszard W. Wołoszyński, Polska $w$ opiniach Francuzów w XVIII w. Rulhière $i$ jego wspótcześni (Warsaw, 1964); Emanuel Rostworowski, 'Voltaire et la Pologne', Studies on Voltaire and the Eighteenth Century, 62 (1968), 101-21.

${ }^{55}$ Jerzy Michalski, Rousseau i sarmacki republikanizm (Warsaw, 1977); idem, Sarmacki republikanizm $w$ oczach Francuza. Mably $i$ konfederaci barscy (Monografie Fundacji na Rzecz Nauki Polskiej, Wrocław, 1995); cf. Graham Gargett, Voltaire and Protestantism (Studies on Voltaire and the Eighteenth Century, 188, Oxford, 1980), 471-9. 
Given this standpoint, the statement may seem true whereby the sixteenth-century critics of the Commonwealth's religious relations were all-in-all right: the conflict about which attempts had been made to render it religious indeed contributed to the collapse of the PolishLithuanian nobility's state. The question about the sequence of the causes and effects still remains valid, though. This question extends to identifying the factors that, in the sphere of religious relations, had a stronger bearing on the debilitation of the Polish-Lithuanian Commonwealth: equality in rights to the Christian denominations in the sixteenth century; quitting this policy in favour of tolerance, permanently limited afterwards, for non-Catholics in the late sixteenth and early seventeenth century; or, the making in the latter half of the seventeenth century of one more, this time much belated, attempt at reinstating a confessional state model, with all its later consequences to the state and country.

trans. Tristan Korecki 